\title{
Floral anatomy of the plant Psittacanthus schiedeanus (Loranthaceae)
}

Camila Robayo ${ }^{1}$, Xavier Marquínez $^{1 *}$, Lauren Raz $^{2} \&$ Daniel Lee Nickrent ${ }^{3}$

1. Departamento de Biología, Facultad de Ciencias, (Sisbio, COL0024669), Universidad Nacional de Colombia-Sede Bogotá, Carrera 30 \# 45-03, Bogotá D.C., Colombia; carobayom@unal.edu.co, xmarquinezc@unal.edu.co

2. Instituto de Ciencias Naturales, Facultad de Ciencias, Universidad Nacional de Colombia-Sede Bogotá, Carrera 30 \# 45-03, Bogotá D.C., Colombia; 1raz@unal.edu.co

3. Department of Plant Biology, Southern Illinois University, Carbondale, Illinois 62901 USA; nickrent@plant.siu.edu * Correspondence

Received 28-V-2019. Corrected 06-VIII-2019. Accepted 25-X-2019.

\begin{abstract}
Anatomía floral de la planta Psittacanthus schiedeanus (Loranthaceae). Loranthaceae hemiparasitic family comprises 76 genera and about 1050 species distributed in temperate and tropical regions. The subtribe Psittacanthinae contains 14 genera of neotropical mistletoe including Psittacanthus with over 120 species, characterized by large, brightly colored (red, orange, yellow) flowers that are mostly pollinated by hummingbirds. During the $20^{\text {th }}$ century, a number of morphological and embryological studies were conducted mainly on Old World Loranthaceae genera. More recently, attention has been focused on neotropical Psittacanthinae where among the 14 genera, floral anatomy has been examined in only seven. The aim of this study is to describe the floral anatomy of Psittacanthus schiedeanus and compares the results with those derived from related mistletoe, interpreting the variation of the floral characters of the calyculus, nectary, gynoecium and from floral dissections and serial histological sections, detailing the structure of androecium and gynoecium and anthers in the context of the new phylogenetic information. Flowers of $P$. schiedeanus at different developmental stages were examined using stained serial sections visualized with light microscopy. These flowers have a vascularized, cupular pedicel fused to a bracteole, a non-vascularized calyculus, an annular nectary, a unilocular gynoecium with a single central mamelon and an androecium formed by epipetalous septate stamens. The morphological comparison of pedicel, bracteole and calyculus provides support for the interpretation of the calyculus as a reduced calyx. The annular nectary seems to be a character shared by the entire subtribe Psittacanthinae, which distinguishes it from Ligarinae which has stylar nectary. The unilocular gynoecium formed by a single central structure is a character shared with other genera in Psittacanthinae except Tripodanthus. The androecium is composed of dithecal, tetrasporangiate stamens with septate locules that are here considered an adaptation for pollen releasing over an extended time period rather than previous suggestions that they result from evolutionary pressure to reduce anther size or to facilitate the nutrition of microspores in large anthers.
\end{abstract}

Key words: Aetanthus, androecium, annular nectary, calyculus, cupular pedycel, gynoecium, septate anthers.

Robayo, C., Marquínez, X., Raz, L., \& Nickrent, D.L. (2020). Floral anatomy of the plant Psittacanthus schiedeanus (Loranthaceae). Revista de Biología Tropical, 68(1), 1-11.

The mistletoe family Loranthaceae Juss. (Santalales) comprises 76 genera and ca. 1050 species (Nickrent, 1997; Kuijt, 2009) distributed mostly in tropical regions, with a lower representation in the temperate zones
(Barlow, 1983; Liu et al., 2018). Based on molecular, karyological and morphological evidence, Loranthaceae was divided into five tribes by Nickrent, Malécot, Vidal-Russell, and Der (2010). Tribe Psittacantheae was further 
subdivided into four subtribes, including the neotropical Psittacanthinae with 14 genera 319 species (Nickrent, 1997). A recent study examined inflorescence evolution in the sandalwood order and reported a well-resolved molecular phylogeny sampling 62 of the 76 genera of Loranthaceae (Nickrent, Anderson, \& Kuijt 2019). That analysis showed that Tribe Psittacantheae is not monophyletic (as previously hypothesized by Nickrent et al., 2010) because of new positions for Tupeia Cham. \& Schltdl. and Desmaria Tiegh. In contrast, clades representing Subtribes Ligarinae and Psittacanthinae were well-supported. Most of the genera in the latter subtribe contain small, insect-pollinated flowers, however, two sister genera Aetanthus (Eichler) Engl., and Psittacanthus (Mart). have the largest flowers of all neotropical mistletoes. These genera are characterized by large, brightly colored (red, orange, yellow) flowers that are mostly hummingbird pollinated (Ornelas et al., 2016). Aetanthus is a high elevation mistletoe with 15 species (Kuijt, 2014) whereas Psittacanthus with 121 species (updated from Kuijt, 2009) occurs from low to high elevations with a wide geographic distribution. Psittacanthus is mainly a continental genus, ranging from Baja California to Bolivia and Argentina with only four species being found in the Caribbean (Kuijt, 2009). The genus is characterized by its large haustorial connections (Kuijt, 2009; Gómez-Sánchez, Sánchez-Fuentes, \& Salazar-Olivo, 2011) that form massive woodroses (rosa de palo, flor de palo) on host branches. The black fruits contain polycotyledonous embryos and no endosperm (Kuijt, 1967, 2009, 2018).

Psittacanthus schiedeanus is found in Mexico, Costa Rica, Honduras, El Salvador, Guatemala, Panama and possibly Belize. Nicaragua represents a gap in its distribution and the Northern and Southern populations show some morphological differentiation (Kuijt 2009). The species parasitizes over 20 different hosts (Ornelas et al., 2016; Cocoletzi, Angeles, Ceccantini, Patrón, \& Ornelas, 2016) and it is considered part of a species complex involving P. calyculatus (DC.) G. Don, P. breedlovii
Kuijt, and P. angustifolius Kuijt (Diaz-Infante, Lara, del Coro Arizmendi, Eguiarte, \& Ornelas, 2016; Pérez-Crespo et al., 2017). This robust mistletoe can reach $3 \mathrm{~m}$ in diameter, has large leaves (up to $20 \mathrm{~cm}$ long), and a terminal inflorescence consisting of three to five pairs of triads. Both the triads and the individual flowers are subtended by cupular bracts and bracteoles, respectively. The yellow, orange or red flowers are up to $9 \mathrm{~cm}$ in length in bud and have a smooth calyculus. Upon anthesis the six petals reflex exposing the dimorphic stamens whose filaments can reach $3 \mathrm{~cm}$ in length. The anthers are alveolate and polysporangiate, a feature seen in relatively few members of the genus. The straight, smooth style is approximately as long as the stamens. The black fruit has an embryo with 6-13 awl-shaped cotyledons (Kuijt, 2009).

It can be argued that the most important early work on Loranthaceae floral morphology began with Eichler (1868) with his seminal treatment of the family in Flora Brasiliensis. This work was followed by Engler (Engler, 1889; Engler \& Krause, 1935) whose contributions provided detailed illustrations of floral sections of Macrosolen (Blume) Blume, Dendrophthoe Mart. and Psittacanthus. During the mid-20th century, a number of morphological and embryological studies were conducted on Old World genera (Johri, Agrawal, \& Garg, 1957; Narayana, 1958; Prakash, 1961), however, little work was done on New World mistletoes (an exception is Venturelli 1984 on Struthanthus Mart.). More recently, attention has been focused on Psittacanthus (Gómez-Sánchez et al., 2011), Peristethium Tiegh. (Robles, Raz, \& Marquínez, 2016), and six New World genera (Suaza-Gaviria, Pabón-Mora, \& González, 2016). The latter provided insight into the floral anatomy of Psittacanthus acinarius and P. krameri Kuijt. An anatomical study of the ovary and seedling of P. schiedianus was conducted (Kuijt, 1967), however, structures from the entire mature flower were not included. This paper describes the floral anatomy of Psittacanthus schiedeanus and compares the results with those 
derived from related mistletoes. The observed variation in floral characters such as the calyculus, nectary, gynoecium and polysporangiate anthers are interpreted in the context of new phylogenetic information.

\section{MATERIALS AND METHODS}

Study site: A specimen of Psittacanthus schiedeanus parasitizing Drimys granadensis L.f. (Winteraceae) was collected on August 18, 1993 in Heredia Province, Costa Rica, along the Southern slopes of Volcan Barva, near Porrosati $\left(10^{\circ} 05^{\prime} 44.76^{\prime \prime} \mathrm{N} \& 8^{\circ} 06^{\prime} 41.83^{\prime}\right.$ ' W, 2027 m.a.s.1.), specimen voucher D. L. Nickrent \& Shu-Chuan Hsiao 3012 SIU (Fig. 1A).

Data processing and analyses: Samples of floral buds, flowers in preanthesis and anthesis were fixed in FAA (formaldehyde: acetic acid: $70 \%$ ethanol, 10:5:85), stored in $70 \%$ ethanol, and subsequently treated following the protocol of Robles et al. (2016). This involved standard methods of dehydratation using a clearing agent (Histoclear), paraffin infiltration, sectioning with a rotary microtome $(820$ Spencer, American Optical Company, NY) and attachment to microscope slides. The slides were stained with astra-blue and fuchsine and deposited in the Department of Biology collection at the Universidad Nacional de Colombia, Bogotá. They were analyzed and photographed using an Olympus BX-50 microscope with a Moticam Pro 282B camera. Fixed flowers were studied with a Leica M205A stereoscope using multifocus mode and photographed with a Leica MC 170 HC camera. Digital images were processed and edited with the Adobe programs Photoshop CC and InDesign.

\section{RESULTS}

Morphology of inflorescences and flowers: Psittacanthus schiedeanus exhibits terminal racemose inflorescences formed by pairs of triads (Fig. 1A). On the main inflorescence axis, secondary axes (peduncles of the triads) are inserted that culminate in acute cupular bracts. From each bract arise three floral cupular pedicels whose apices are dilated and fused with the associated bracteoles that subtend the inferior ovaries of the flowers (Fig. 1B, Fig. 1D). The bisexual flower buds (preanthesis) are 8-9 cm long. The calyculus is annular and has approximately six small but well-differentiated teeth. The corolla consists of six straight yellow to orange petals, $8-9 \mathrm{~cm}$ long and 1-2 mm wide, free from the base, although joined postgenitally in the floral bud by interdigitation of the epidermal cells (Fig. 2B, Fig. 2C). At anthesis the petals curl outward from the apex, exposing the $7-8 \mathrm{~cm}$ long straight stamens that spread away from each other and the style (Fig. 1B, Fig. 1C). The androecium has six dimorphic (three long and three short) stamens attached to the base of the petals by their filaments. The anthers are dorsifixed and introrse (Fig. 1C). Surrounding the base of the style is a small nectariferous ring. The style is straight, slightly longer than the stamens and is terminated by a differentiated red stigma (Fig. 1A, Fig. 1C).

Cupular pedicel and inferior ovary: For the centrally inserted flower of the triad, the cupular part of the pedicel with its associated bracteole shows vascularization up to half of its length (Fig. 1D). For flowers in anthesis, the floral base below the hypostase consists of a uniseriate epidermis, formed by small, quadrangular cells with very thin external cuticles and irregular internal faces, followed by two to three layers of parenchymatous cells similar in size to the epidermis, which in turn are succeeded by large parenchymatous cells forming 10-12 layers of tissue, and, finally, a ring formed by eight layers of small and tanniferous parenchymatous cells. Internally, surrounded by typical parenchyma, there are six collateral vascular bundles and a central parenchymatous cortex (Fig. 1E).

The hypostase, formed by modified nucellar cells that delimit the downward growth of the embryo sac (see Johri, Ambegaokar, \& Srivastava, 1992), is broad and sclerenchymatous and subtends the inferior ovary (Fig. 1G). 

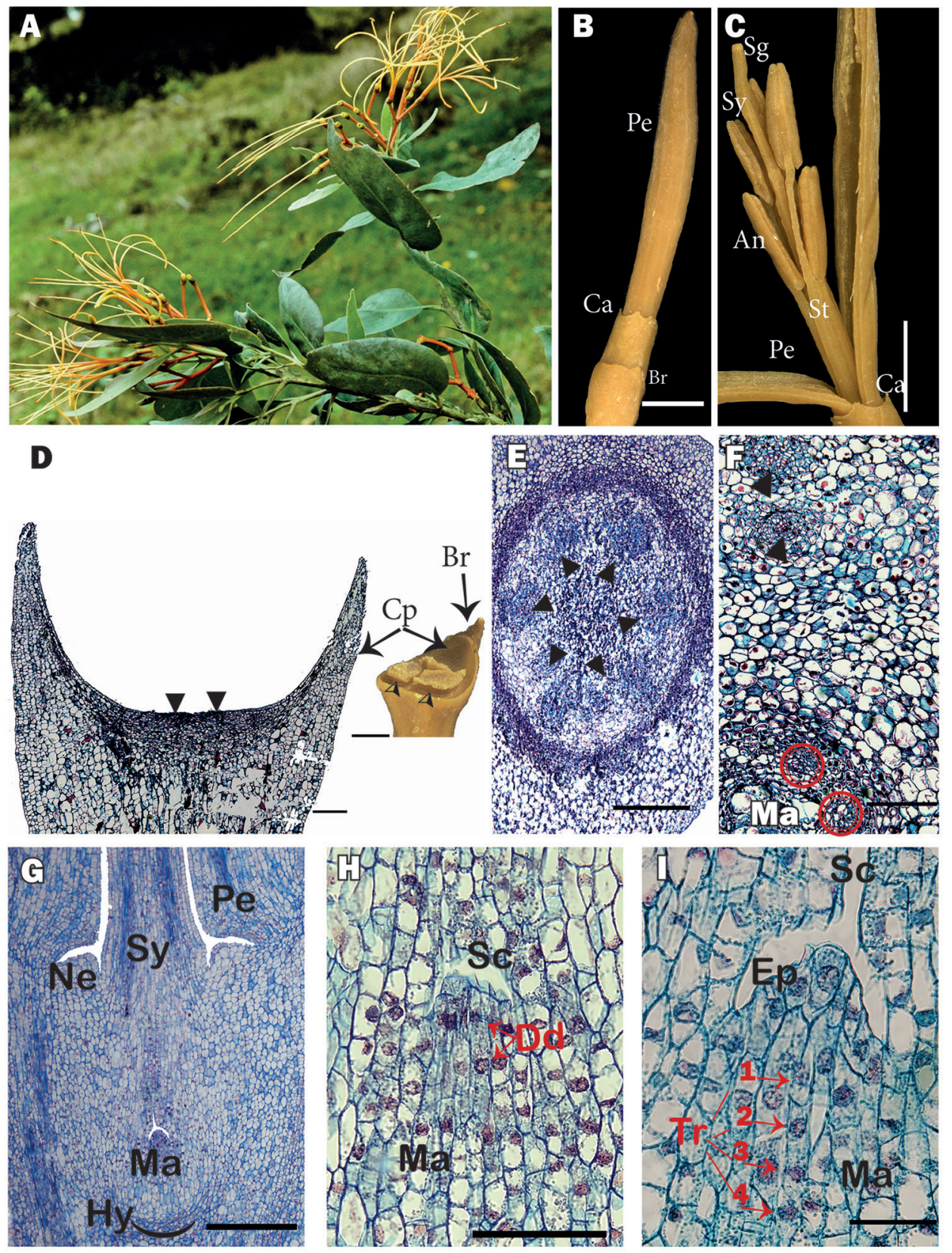

Fig. 1. A. Flowering shoot of Psittacanthus schiedeanus (voucher Nickrent \& Hsiao 3012). B. Lateral view of a flower bud. C. A. preanthesis flower bud opened. D. External view (inset - a estereomicroscope image) of the cupular pedicel and bracteole, the flower was removed; black arrowheads $(\boldsymbol{\nabla})$ indicate the place where the flower is typically inserted. E. Cross section of the flower at the floral base level. F. Cross section just above the hypostase level; the black triangle indicates the internal vascular bundles and the red triangle with the red circles indicate the gynoecium bundles. G. Longitudinal section of a flower showing the lower portion containing the inferior ovary. H. Mamelon with dyads. I. Mamelon with tetrads. An= anther, $\mathbf{B r}=$ bracteole, $\mathbf{C a}=$ calyculus, $\mathbf{C p}=$ cupular pedycel, $\mathbf{D d}=$ dyads, $\mathbf{E} \mathbf{p}=$ epidermis, $\mathbf{H y}=$ hypostase, $\mathbf{M a}=$ mamelon, $\mathbf{N e}=$ nectary, $\mathbf{P e}=$ petal, $\mathbf{S c}=$ Stylar canal, $\mathbf{S g}=$ stigma, $\mathbf{S t}=$ stamen, $\mathbf{S y}=$ Style, $\mathbf{T r}=$ tetrads. Scales: $\mathbf{5} \mathbf{~ m m ~ i n ~} \mathbf{B}$ and $\mathbf{C}$, $\mathbf{5 0 0} \boldsymbol{\mu m}$ in $\mathbf{G}$ and $\mathbf{D}$, and $\mathbf{1 0 0} \boldsymbol{\mu m}$ in $\mathbf{E}, \mathbf{F}, \mathbf{H}, \mathbf{I}$. (Color in digital version). 
The six basal vascular bundles divide leading to six external groups of two vascular bundles, which cross the ovary wall and innervate the petals and stamens. More internally, one finds four to five ovary vascular bundles, which surround the central amyliferous parenchymatous tissues, inside of which is the mamelon (Fig. 1F). The mamelon has an external epidermis that is oriented towards the stylar canal (Fig. 1G, Fig. 1H). The subepidermal cells divide, giving rise to dyads (Fig. 1H) and then linear tetrads (Fig. 1I). At anthesis, four to six very elongated embryo sacs originate, one cell from each of the four to six tetrads. These embryo sacs are directed towards the style and invade its base through the interior of the central transmission tissue (Fig. 2A).

Towards the middle of the inferior ovary of the flower in anthesis, between the external vascular bundles and the internal vascular bundles of the gynoecium, around and above the mamelon, a ring of several layers of amiliferous parenchyma with immersed phloemic vascular tissue is located below the annular nectary (Fig. 1G).

Calyculus and corolla: The calyculus presents a uniseriate epidermis with a very thin cuticle; the internal tissues are parenchymatous and no vascular bundles are present. The corolla is formed by free petals, with the stamens attached at their bases (Fig. 2B). Anatomically, the abaxial (external) surface of the petals has a uniseriate epidermis composed of cells with a thin cuticle but thickened walls. Laterally, the epidermis shows interdigitations that interconnect the petals postgenitally (Fig. 2B, Fig. 2C). On the adaxial (internal) surface, the epidermis is more irregular and no stomata are seen. Each petal has a narrow base, an intermediate laminar zone and a narrow apex. In all areas, mesophyll tissue is collenchymal and has a central vascular bundle. Two lateral vascular bundles are also present in the laminar zone. The adaxial surface of the petal has one median ridge and apically, in the place where the anthers and the stigma culminate, it exhibits projections (knee-like prominences, Fig. 2D).
These internally fit with the stamens and also with the style, helping to give support to a very long floral tube (Fig. 2B).

Nectary, style and stigma: Between the petals and the style base, an annular nectary is present (Fig. 1G). The style is initially hollow, but later the internal epidermal tissues join and, together with the amiliferous parenchyma that surrounds them, form an internal transmission tissue (Fig. 2D). Surrounding this are 4-5 vascular bundles, and more externally, two to three layers of typical parenchyma and finally a thick-walled epidermis whose cells have a prominent external cuticle (Fig. 2D). The slightly differentiated stigma and has extremely rounded cells (not shown).

Androecium: The long, cylindrical filament is adnate to the base of the petals. Anatomically, it consists of a uniseriate epidermis that lacks stomata and whose cell walls have a thick cuticle. Internally, 2-3 layers of typical parenchyma are seen surrounding a central vascular bundle (Fig. 2B). The anthers are dimorphic, dorsifixed, versatile (Fig. 1C) and dithecal (tetrasporangiate) with the four locules (pollen sacs) being of similar size (Fig. 2F). Longitudinally, each pollen sacs is divided into six to seven separate "pockets" (Kuijt 2009) separated by septae (Fig. 2E). The epidermis is made up of flattened cells that collapse in the mature anther. The endothecium is represented by a layer of quadrangular cells, each of which contains secondary thickenings (fibrous bands). Some cells of the middle layer and part of the parenchymatous cells between the pollen and connective sacs also show thickenings. The tapetum is glandular, non-intrusive and degradate in anthers with mature pollen (Fig. 2F). The dehiscence of the anthers occurs as a consequence of the breaking of the union between the wall of each pollen sac and the thick partition that separates them in each theca. The anthers found in the flower buds and open flowers had fully developed pollen. 

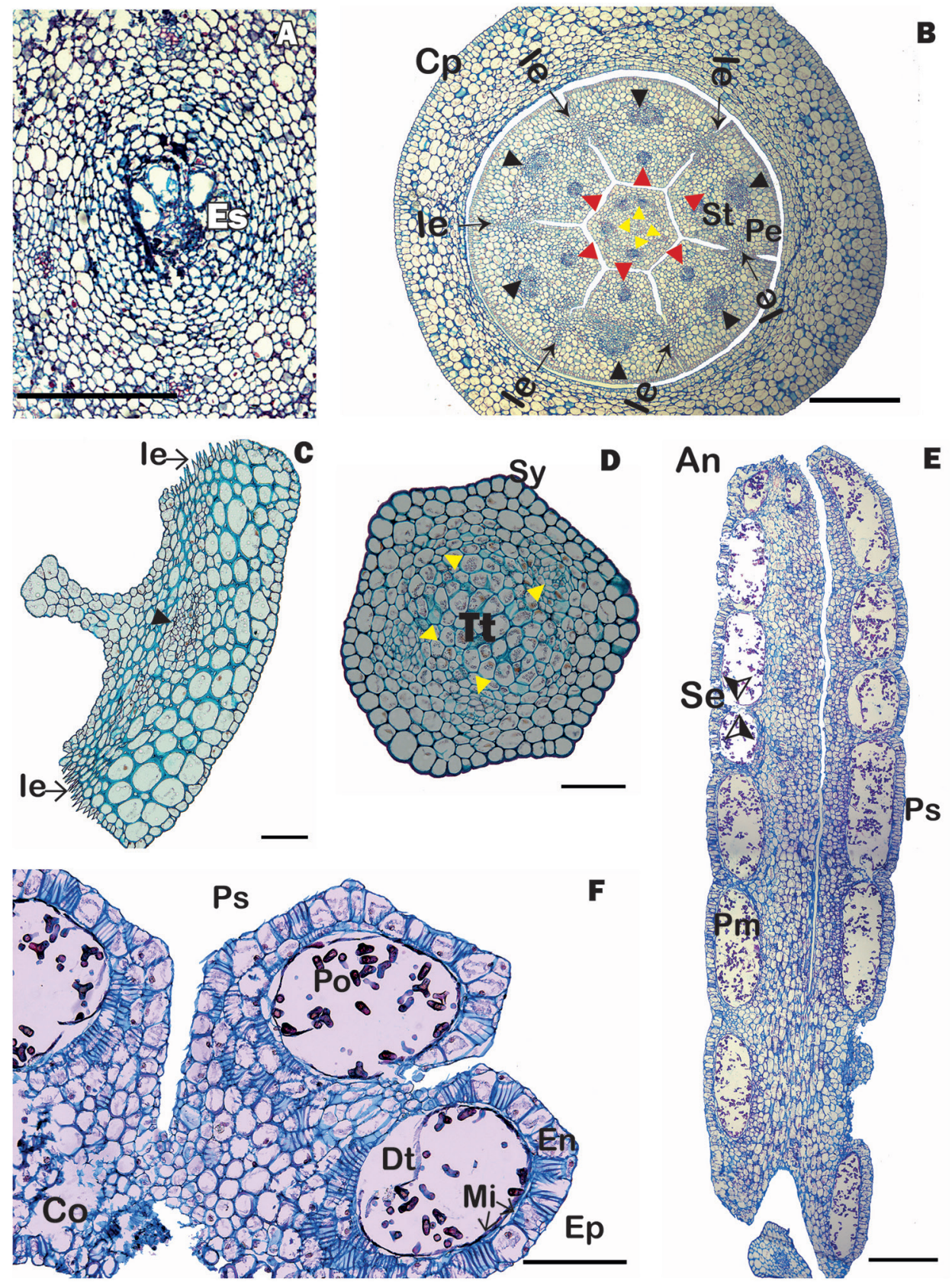

Fig. 2. (Color in digital version) A. Cross section of mamelon with embryo sacs. B. Cross section of the flower at the level of the style base and calyculus (red arrowheads = vascular bundles of the stamens; black arrowheads = vascular bundle of the petals, yellow arrowheads = vascular bundle of the style), C. Cross section of a petal, D. Cross section of the style, E. Longitudinal section of an anther; F. Cross section of an anther showing pollen sacs with mature pollen. An $=$ anther, Co = connective, $\mathbf{C p}=$ cupular pedicel, $\mathbf{D t}=$ degenerated tapetum, $\mathbf{E n}=$ endothecium, $\mathbf{E s}=$ embryo sacs, $\mathbf{E p}=$ epidermis, $\mathbf{I e}$ $=$ interdigitated epidermis, $\mathbf{M i}=$ middle layer, $\mathbf{P e}=$ petal, $\mathbf{P m}=$ madure pollen, $\mathbf{P o}=$ Pollen, $\mathbf{P s}=$ pollen sac, $\mathbf{S e}=$ septum, $\mathbf{S t}=$ stamen, $\mathbf{S y}=$ style, $\mathbf{T t}=$ transmission tissue. Scales: $500 \mu \mathrm{m}$ in $\mathbf{B}, \mathbf{E} ; 200 \mu \mathrm{m}$ in F; $150 \mu \mathrm{m}$ in $\mathbf{C} ; \mathbf{1 0 0} \mu \mathrm{m}$ in $\mathbf{A}, \mathbf{D}$. (Color in digital version). 


\section{DISCUSSION}

The morphological and anatomical features of Psittacanthus schiedianus described here, generally conform with those reported for this species in Kuijt (2009) and with features seen in $P$. acinarius and P. krameri (Suaza et al., 2016). Although Kuijt (1967) reported anatomical features for P. schiedianus, the paper's focus was on fruits and seeds, hence the current study helps complete the developmental stages beginning with flowers. As noted by Kuijt (2009), most of the floral structural diversity in Psittacanthus involves the anthers, hence anatomical details of the alveolate condition for $P$. schiedianus extends the range of information for the genus.

A comparative morphological approach would best be guided by a robust molecular phylogeny. Although some species relationships in Psittacanthus have been addressed using molecular markers (Ornelas et al., 2016; Ortiz-Rodriguez, Guerrero, \& Ornelas, 2018), only 17 of the 121 species have sequences in NCBI Genebank (https://www.ncbi. nlm.nih.gov/Taxonomy/Browser/wwwtax. cgi?id=50160). Despite low sampling, these studies have shown that $P$. schiedianus is in a clade with $P$. acinarius, $P$. breedlovei, $P$. calyculatus, $P$. mayanus and $P$. rhynchanthus. Morphologically, all of these species share terminal triadic inflorescences (Kuijt, 2009). The cupular pedicel in Psittacanthus schiedeanus is bracteolate with vascularization, a character is also present in Psittacanthus acinarius, P. krameri (Suaza-Gaviria et al., 2016) and Aetanthus mutissi (Kuijt, 2013). Psittacanthus schiedeanus has a calyculus without vascularization and with a dentate margin. The margin was described as "smooth" in Kuijt (2009), however, our specimen (and others examined) show a dentate margin, a character that coincides with the five related species listed above as well as with Aetanthus mutissi (Kuijt, 2014; Suaza et al., 2016). This feature could be polymorphic within a species (variable between populations), as suggested by the presence of smooth and dentate calyculi in $P$. acinarius (Kuijt, 2009).

The rim of tissue that arises from the top of the ovary in all Loranthaceae has been referred to as a calyculus (Brown, 1827; Baillon, 1862) and has traditionally been interpreted as a reduced calyx (although not universally). Wanntorp and Ronse De Craene (2009) proposed a prophyllar (bracteolar) origin of this structure; however, this view was rejected by Kuijt (2013), who supported the traditional interpretation. For Psittacanthus, two anatomically different structures, a cupped, bracteolate and vascularized pedicel and a non-vascularized toothed calyculus occur together in the same species, thus supporting the interpretation of the calyculus as a reduced calyx (Kuijt, 2013). In Loranthaceae, the calyculus is either vascularized or not. Vascular traces are present within the calyculus in the early-diverging genera Nuytsia R. Brown ex G. Don f. (Narayana, 1958), Atkinsonia F. Muell. (Garg, 1958; Prakash, 1961), and Gaiadendron G. Don. (Van Tieghem, 1895). With the exception of Desmaria (Van Tieghem, 1895), the calyculus in the rest of the family lacks vascularization (Gómez-Sánchez et al., 2011; Kuijt, 2013).

Although Engler (1889) interpreted some species of Psittacanthus as having free petals and others with petals fused at the base, Kuijt (2009) pointed out that this union occurs by interdigitation of the epidermal cells of the contiguous petals. On the other hand, this postgenital union of petals is more evident in some species during anthesis, while, as noted by Kuijt (2009), in species with filamentous petals, the flowers open all the way to the base with the petals strongly curling. In the case of P. schiedeanus, Ramírez and Ornelas (2010) indicate that the petals diverge in anthesis completely, so that no discernible "floral tube" is observed. These same authors note that the staminal filaments are inserted very low on the petals, which coincides with our observations (Fig. 2C). They conclude that the "filament length and level of filament insertion may be related to pollination mode" (Ramírez \& Ornelas, 2010) 
Kuijt (2009) stated that most species of Psittacanthus have tetrasporangiate stamens, but in about seven species, including $P$. schiedeanus, a septate condition has developed in which each microsporangium shows a longitudinal series of "separate, small pockets that appear to dehisce by means of minute, separate apertures". We confirmed this condition in $P$. schiedeanus (Fig. 2E), and it has been observed by Suaza et al. (2016) in Aetanthus mutissi, but not in $P$. acinarius and $P$. krameri. The presence of septae in anthers has been explained in various ways. Lersten (1971) proposed that this is an intermediate morphological step being driven by evolutionary pressure for size reduction. Other hypotheses propose that the formation of anther septae can facilitate the nutrition of microspores that develop in large anthers (Suaza et al., 2016), or that there is a critical size of the sporangium or sporangium/tapetum ratio which cannot be surpassed, thus requiring the subdivision of larger anthers (Endress \& Stumpf, 1990). Psittacanthus is a good model to test these hypotheses. The monograph of Kuijt (2009) recognizes 119 species for the genus, seven of them with septate anthers of $5.8 \pm 1.2 \mathrm{~mm}$; while in the 112 species with non-septate anthers, these vary between 1.5 to $24 \mathrm{~mm}$ in length, with an average of $4.8 \pm 2.7$ $\mathrm{mm}$. Clearly, the septate anthers are within the average length-range for the genus. Among the 15 species of Aetanthus (Kuijt, 2014), only $A$. mutissi has septate anthers (Suaza et al., 2016) that measure $14-15 \mathrm{~mm}$ in length, thus falling within the average range for the genus (13.5 \pm $2.5 \mathrm{~mm}$ ). Therefore, the similar length between septate and non-septate anthers indicates that the second hypothesis cannot explain the presence of septate anthers in these neotropical mistletoes. The first hypothesis of Lersten (1971) could be tested by conducting morphometrics analyses over molecular phylogenies on the genus. Here we propose an alternative hypothesis by considering that the dehiscence of each pocket of the anther loculus of $P$. schiedeanus is independent, as Kuijt (2009) affirms, and possibly not simultaneous. Given that the duration of flower anthesis in P. schiedeanus is documented to last for six days (Ramírez \& Ornelas, 2010), this mechanism would allow for the release of pollen to different pollinators over an extended period of time. This proposed mechanism of controlled pollen release from septate anthers has been observed in the genera Microlicia and Chaetostoma of Melastomataceae (Baumgratz, Souza, Woodgyer, \& Lughadha, 1996).

It appears that at least two subtribes of Psittacantheae (Psittacanthinae and Ligarinae), propossed by Nickrent et al. (2010), and phylogenetically supported by Nickrent et al. (2019) can be distinguished from each other by nectary type. Psittacanthus schiedeanus has an inconspicuous annular (ring-shaped) nectary, located between the petals and the style base, a character shared with other studied genera in Psittacanthinae: Peristethium (Robles et al., 2016), Passovia, Aetanthus and Oryctanthus (Suaza et al., 2016), Struthanthus (Venturelli, 1981, 1984) and Cladocolea (Kuijt, 1975; Cid Villamil, 2006). In subtribe Ligarinae, Ligaria has a nectary formed by the thickened and modified base of the style (Galetto, Bernardello, \& Juliani, 1990; Kuijt, 1990) and Tristerix has a "supraovary nectary disk" (González \& Pabon-Mora, 2017).

In Loranthaceae the gynoecium occurs in two different configurations. In the early diverging genera Nuytsia, Gaiadendron and Atkinsonia (Narayana, 1958; Prakash, 1961), and in subtribe Elytrantheae the ategmic ovules (sensu Cocucci \& Venturelli, 1982) are distinguishable in multiple locules. In the rest of the family no separate ovules are distinguishable, they apparently having become fused into a single structure called the mamelon (Brown, Nickrent, \& Gasser, 2010) or "collective ovule" (Cocucci, 1983) within a single loculus. In the most recent phylogeny of Loranthaceae (Nickrent et al., 2019), Aetanthus and Psittacanthus are sister genera with strong support, but this clade is unresolved with respect to the small flowered members of subtribe Psittacanthinae. Sister to all Psittacanthinae, the genus Tripodanthus is a genus that retains gynoecial features seen in the early diverging genera. 
It is characterized by having distinguishable "ategmic ovules" in three separate locules (Cocucci, 1983; Cocucci \& Venturelli, 1982; Venturelli, 1983). In contrast, Psittacanthus shares with Aetanthus and the rest of subtribe Psittacantheae (except Tripodanthus) the derived condition with unique and unilocular gynoecial structure.

Ethical statement: authors declare that they all agree with this publication and made significant contributions; that there is no conflict of interest of any kind; and that we followed all pertinent ethical and legal procedures and requirements. All financial sources are fully and clearly stated in the acknowledgements section. A signed document has been filed in the journal archives.

\section{RESUMEN}

Anatomía floral de Psittacanthus schiedeanus (Loranthaceae). La familia hemiparásita Loranthaceae comprende 76 géneros y aproximadamente 1050 especies distribuidas en regiones templadas y tropicales. La subtribu Psittacanthinae contiene 14 géneros de muérdagos neotropicales que incluyen Psittacanthus con más de 120 especies, caracterizadas por presentar flores grandes de colores brillantes (rojo, naranja y amarillo) que son polinizadas principalmente por colibríes. Durante el siglo XX se desarrollaron una serie de estudios morfológicos y embriológicos de géneros de Loranthaceae del Viejo Mundo. Recientemente, la atención se ha centrado en la subfamilia neotropical Psittacanthinae, en donde de los 14 géneros que la conforman, la anatomía floral se ha examinado solamente en siete. El objetivo de este estudio es describir la anatomía floral de Psittacanthus schiedeanus y comparar los resultados con los de otros muérdagos relacionados, interpretando la variación de los caracteres florales del calículo, nectario, gineceo y anteras en el contexto de la nueva información filogenética. Flores de $P$. schiedeanus en diferentes estados de desarrollo fueron examinadas mediante secciones seriadas teñidas utilizando microscopía óptica. Estas flores tienen un pedículo vascularizado y cupular fusionado con una bracteola, un cáliz no vascularizado, un nectario anular, un gineceo unilocular con un solo mamelón central y un androceo formado por estambres septados epipétalos. La comparación morfológica de pedicelo, bracteola y calículo proporciona apoyo para la interpretación del calículo como un cáliz reducido. El nectario anular parece ser un carácter compartido por toda la subtribu Psittacanthinae, que lo diferencia de la subtribu Ligarinae con nectario estilar. El gineceo unilocular formado por una estructura central única es un carácter compartido con otros géneros de la subtribu Psittacanthinae, con la excepción de Tripodanthus. El androceo está formado por estambres bitecados, tetrasporangiados con lóculos septados que aquí se consideran una adaptación para liberar polen durante un período prolongado de tiempo, en lugar de sugerencias previas que lo explican como resultado de la presión evolutiva para reducir el tamaño de la antera o para facilitar la nutrición de microesporas en anteras grandes.

Palabras claves: Aetanthus, androceo, anteras septadas, calículo, gineceo, nectario anular, pedicelo acopado.

\section{REFERENCES}

Baillon, H. E. (1862). Mémoire sur les Loranthacées. Adansonia, 2(3), 30-381.

Barlow, B. A. (1983). Biogeography of Loranthaceae and Viscaceae. In M. Calder \& P. Bernhardt (Eds.), The biology of Mistletoes (pp. 19-46). Sidney: Academic Press.

Baumgratz, J. F. A., Souza, M. L. D. R., Woodgyer, E. M., \& Nic Lughadha, E. M. (1996). Polysporangiate anthers: described for the first time in Melastomataceae. Kew Bulletin, 51(1), 133-144.

Brown, R. (1827). Prodromus florae Novae Hollandiae et Insulae Van-Diemen: exhibens characteres plantarum (Vol. 3). Taylor, London: Sumtibus L. Schrag.

Brown, R. H., Nickrent, D. L., \& Gasser, C. S. (2010). Expression of ovule and integument associated genes in reduced ovules of Santalales. Evolution \& Development, 12(2), 231-240.

Cid Villamil, R. M. (2006). Biología del desarrollo de Cladocolea loniceroides (Van Tieghem) Kuijt (Loranthaceae) (Doctoral dissertation). Universidad Nacional Autónoma de México, México, D.F., México.

Cocoletzi, E., Angeles, G., Ceccantini, G., Patrón, A., \& Ornelas, J. F. (2016). Bidirectional anatomical effects in a mistletoe- host relationship: Psittacanthus schiedeanus mistletoe and its hosts Liquidambar styraciflua and Quercus germana. American Journal of Botany, 103(6), 986-997.

Cocucci, A. E. (1983). New evidence from embryology in angiosperm classification. Nordic Journal of Botany, $3(1), 67-73$.

Cocucci, A. E., \& Venturelli, M. (1982). El ovulo y el gineceo en Loranthaceae. Boletín de la Sociedad Argentina de Botánica, 21(1-4), 131-141.

Diaz-Infante, S. D., Lara, C., del Coro Arizmendi, M., Eguiarte, L. E., \& Ornelas, J. F. (2016). Reproductive ecology and isolation of Psittacanthus calyculatus 
and P. auriculatus mistletoes (Loranthaceae). PeerJ, 4, e2491.

Eichler, A. W. (1868). Loranthaceae. In C. F. P. Martius \& A. G. Eichler (Eds.), Flora Brasiliensis (Vol. 5, Part 2, pp. 1-136). Leipzig: Fleischer in Comm.

Endress, P. K., \& Stumpf, S. (1990). Non-tetrasporangiate stamens in the angiosperms: structure, systematic distribution and evolutionary aspects. Botanische Jahrbücher für Systematik, Pflanzengeschichte und Pflanzengeographie, 112, 193-240.

Engler, A. (1889). Loranthaceae. In A. Engler \& K. Prantl (Eds.), Die Natürlichen Pflanzenfamilien (Vol. 3, pp. 156-198). Leipzig: Wilhelm Engelmann.

Engler, A., \& Krause, K. (1935). Angiospermae: Reihen Santalales, Aristolochiales, Balanophorales. In A. Engler \& K. Prantl (Ed.), Die natürlichen Planzenfamilien (Vol. 1, pp. 98-203). Leipzig: Wilhelm Engelmann.

Galetto, L., Bernardello, L. M., \& Juliani, H. R. (1990). Acerca del nectario, nectar y visitantes florales en Ligaria cuneifolia (Loranthaceae). Darwiniana, 30, 155-161.

Garg, S. (1958). Embryology of Atkinsonia ligustrina (A. Cunn. ex F. Muell.) F. Muell. Nature, 182(4649), 1615-1616.

Gómez-Sánchez, M., Sánchez-Fuentes, L. J., \& SalazarOlivo, L. A. (2011). Anatomía de especies mexicanas de los géneros Phoradendron y Psittacanthus, endémicos del Nuevo Mundo. Revista Mexicana de Biodiversidad, 82(4), 1203-1218.

González, F., \& Pabón-Mora, N. (2017). On the supposed polycotyledony and lack of endosperm in Psittacanthus (Loranthaceae). Brittonia, 69(2), 176-185.

Johri, B. M., Agrawal, J. S., \& Garg, S. (1957). Morphological and embryological studies in the family Loranthaceae. I. Helicanthes elastica (Desr.) Dans. Phytomorphology, 7(3-4), 336-354.

Johri, M., Ambegaokar, B., \& Srivastava, S. (1992). Comparative Embryology of Angiosperms. Berlin: Springer-Verlag.

Kuijt, J. (1967). On the structure and origin of the seedling of Psittacanthus schiedeanus (Loranthaceae). Canadian Journal of Botany, 45(9), 1497-1506.

Kuijt, J. (1975). The genus Cladocolea (Loranthaceae). Journal of the Arnold Arboretum, 56(3), 265-335.

Kuijt, J. (1990). A second species of Ligaria (Loranthaceae). Brittonia, 42(1), 66-69.

Kuijt, J. (2009). Monograph of Psittacanthus (Loranthaceae). Systematic Botany Monographs, 86. American Society Plant Taxonomy, 86, 1-361.
Kuijt, J. (2013). Prophyll, calyculus, and perianth in Santalales. Blumea-Biodiversity, Evolution and Biogeography of Plants, 57(3), 248-252.

Kuijt, J. (2014). A monograph of the genus Aetanthus (Loranthaceae). Plant Diversity and Evolution, 131(1), 1-51.

Kuijt, J. (2018). A rebuttal to a recent article by González and Pabón-Mora (2017) claiming the absence of polycotyly and the presence of endosperm in Psittacanthus (Loranthaceae). Brittonia, 70, 148-149.

Lersten, N. R. (1971). A review of septate microsporangia in vascular plants. Iowa State Journal of Science, 45, 487-497.

Liu, B., Le, C. T., Barrett, R. L., Nickrent, D. L., Chen, Z., Lu, L., \& Vidal-Russell, R. (2018). Historical biogeography of Loranthaceae (Santalales): Diversification agrees with emergence of tropical forests and radiation of songbirds. Molecular Phylogenetics and Evolution, 124, 199-212.

Narayana, R. (1958). Morphological and embryological studies in the family Loranthaceae-III. Nuytsia floribunda (Labill.) R. Br. Phytomorphology, 8, 306-323.

Nickrent, D. L. (1997) onwards. The Parasitic Plant Connection. Retrieved from https://parasiticplants.siu.edu

Nickrent, D. L., Anderson, F., \& Kuijt, J. (2019). Inflorescence evolution in Santalales: Integrating morphological characters and molecular phylogenetics. American Journal of Botany, 106(3), 402-414.

Nickrent, D. L., Malécot, V., Vidal-Russell, R., \& Der, J. P. (2010). A revised classification of Santalales. Taxon, 59(2), 538-558.

Ornelas, J. F., Gándara, E., Vásquez-Aguilar, A. A., Ramírez-Barahona, S., Ortiz-Rodriguez, A. E., González, C., \& Ruiz-Sanchez, E. (2016). A mistletoe tale: postglacial invasion of Psittacanthus schiedeanus (Loranthaceae) to Mesoamerican cloud forests revealed by molecular data and species distribution modeling. BMC Evolutionary Biology, 16(1), 78.

Ortiz-Rodriguez, A. E., Guerrero, E. Y., \& Ornelas, J. F. (2018). Phylogenetic position of Neotropical Bursera-specialist mistletoes: the evolution of deciduousness and succulent leaves in Psittacanthus (Loranthaceae). Botanical Sciences, 96(3), 443-461.

Pérez-Crespo, M. J., Ornelas, J. F., González-Rodríguez, A., Ruiz-Sanchez, E., Vásquez-Aguilar, A. A., \& Ramírez-Barahona, S. (2017). Phylogeography and population differentiation in the Psittacanthus calyculatus (Loranthaceae) mistletoe: a complex scenario of climate-volcanism interaction along the Trans-Mexican Volcanic Belt. Journal of Biogeography, 44(11), 2501-2514. 
Prakash, S. (1961). Morphological and Embryological Studies in the Family Loranthaceae - VII Atkinsonia Ligustrina (Cunningh) F. V. Muell. Phytomorphology, 11, 325-335.

Ramírez, M. M., \& Ornelas, J. F. (2010). Polinización y producción de néctar de Psittacanthus schiedeanus (Loranthaceae) en el centro de Veracruz, México. Boletín de la Sociedad Botánica de México, 87(87), 61-67.

Robles, A., Raz, L., \& Marquínez, X. (2016). Anatomía floral de Peristethium leptostachyum (Loranthaceae). Revista de Biologia Tropical, 64, 341-352.

Suaza-Gaviria, V., Pabón-Mora, N., \& González, F. (2016). Development and morphology of flowers in Loranthaceae. International Journal of Plant Sciences, 177, 559-578.
Van Tieghem, M. P. (1895). Sur le groupement des espèces en genres dans les Loranthées a calice dialysépale et anthères oscillantes ou Struthanthées. Bulletin de la Société Botanique de France, 42(2), 161-180.

Venturelli, M. (1981). Embriologia de Struthanthus vulgaris (Loranthaceae-Loranthoideae). Kurtziana, 14, 73-100.

Venturelli, M. (1983). Estudos embriológicos em Loranthaceae: Gênero Tripodanthus. Kurtziana, 16, 71-90.

Venturelli, M. (1984). Morfologia e anatomia floral de Struthanthus vulgaris Mart.(Loranthaceae). Revista Brasileira de Botânica, 7, 121-128.

Wanntorp, L., \& Ronse De Craene, L. P. R. (2009). Perianth evolution in the sandalwood order Santalales. American Journal of Botany, 96(7), 1361-1371. 